\title{
Median nerve entrapment due to accessory palmaris longus muscle: MRI and sonography findings
}

\author{
Derya Guclu, ${ }^{1}$ Mehmet Arican, ${ }^{2}$ Elif Nisa Unlu ${ }^{3}$
}

'Department of Radiology, Duzce University Mediacl school, Duzce, Turkey

${ }^{2}$ Department of Orthopaedics and Traumatology, Duzce University medical school, Duzce, Turkey

${ }^{3}$ Department of Radiology, Duzce University Medical School, Duzce, Turkey

\section{Correspondence to}

Dr Mehmet Arican,

ari_can_mehmet@hotmail.com

Accepted 18 April 2018

\section{DESCRIPTION}

Peripheral neuropathies of the median nerve at various locations in the upper extremity are common, but compression of the median nerve at the level of the wrist due to an anomalous muscle is rare though presented in the English database. ${ }^{12}$

Here, we present a 35-years-old left-handed woman who had a swelling in the distal third of her left forearm, present since childhood, fluctuating in size and causing paresthesias on the palm.

On physical examination, a swelling on the volar aspect was detected. Electromyography was consistent with carpal tunnel syndrome of moderate severity. MRI revealed a subcutaneous soft tissue of muscle intensity with a lenticular shape (figure 1A,B). Due to its anatomical position, this was identified as a distal muscle belly variation of the palmaris longus muscle. At the distal part of the muscle, the median nerve was
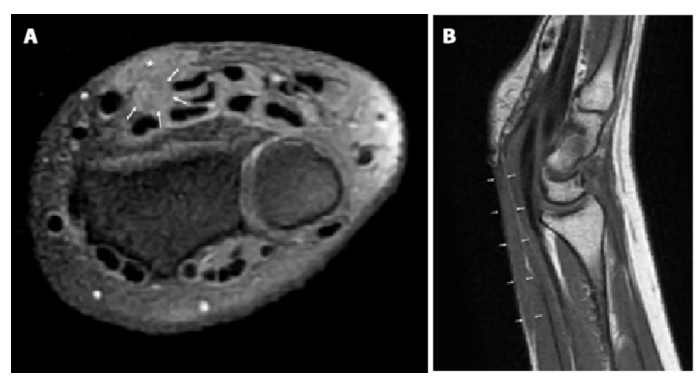

Figure 1 (A) Transverse fat-suppressed Proton density (PD)-weighted image shows increased signal intensity of the median nerve (arrows) dorsal to the accessory muscle $\left.{ }^{(*}\right)$ and $(B)$ accessory palmaris longus muscle is seen on sagittal T1-weighted image of distal forearm and wrist (arrows).

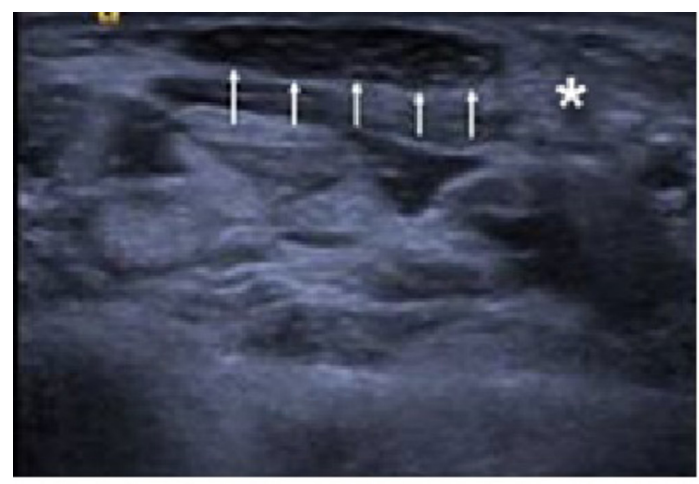

Figure 2 Transverse ultrasound image of the wrist shows the median nerve $\left({ }^{*}\right)$ with increased echogenicity next to the accessory muscle (arrows).
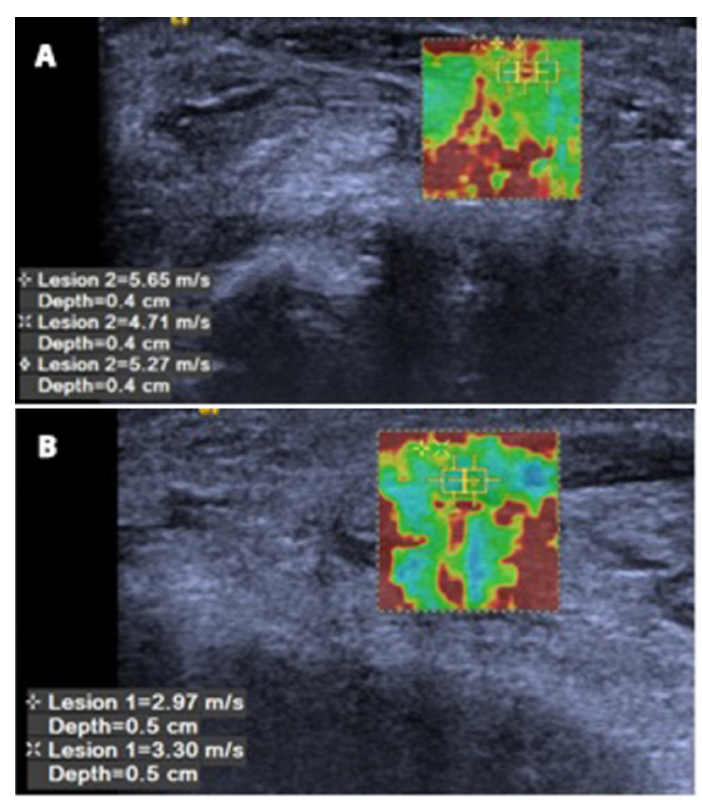

Figure 3 Ultrasound elastography shows the stiffness of the nerve with increased shear wave velocity (A) compared with the normal side (B).

passing through the posterior surface, and there was a segmental thickening and increased signal intensity of the median nerve.

The muscle was confirmed by ultrasonography, and the echogenicity of the median nerve was increased (figure 2). Shearwave elastography detected an increased stiffness at the median nerve (figure 3A,B). Several authors have associated the distal muscle belly variation with nerve entrapment phenomenon at the wrist. ${ }^{2}$

Entrapment is thought to occur due to direct compression but occasionally immediately proximal to the carpal tunnel or muscle lie in a position whereby muscular contraction would lead to compression of the median nerve.

\section{Learning points}

- Compression of the median nerve at the level of the wrist due to an anomalous muscle is rare.

- Accessory palmaris longus muscle could cause dynamic median nerve compression in the wrist.

- Radiological examinations such as ultrasonography and MRI should be performed for differential diagnosis of patients with median nerve compression.

Contributors The idea of the research and hypothesis generation: MA. Planning the methods and hypothesis generation: MA. 
Images in...

Supervision and responsibility for the organisation and course of the project and manuscript preparation: MA and DG. Biological materials reagents, referred patients: MA. Responsibility for conducting experiments, management of patients, organising and reporting data: MA and DG. Responsibility for presentation and logical explanation of results: DG. Responsibility for conducting literature search: DG end ENU. Responsibility for creation of an entire or the substantial part of the manuscript: ENU. Reworking the final, before submission version of the manuscript for intellectual content, not just spelling and grammar check: MA.

Funding The authors have not declared a specific grant for this research from any funding agency in the public, commercial or not-for-profit sectors.

Competing interests None declared.

Patient consent Obtained.
Provenance and peer review Not commissioned; externally peer reviewed.

(C) BMJ Publishing Group Ltd (unless otherwise stated in the text of the article) 2018. All rights reserved. No commercial use is permitted unless otherwise expressly granted.

\section{REFERENCES}

1 De Smet L. Median and ulnar nerve compression at the wrist caused by anomalous muscles. Acta Orthop Belg 2002;68:431-8.

2 Markeson D, Basu I, Kulkarni MK. The dual tendon palmaris longus variant causing dynamic median nerve compression in the forearm. J Plast Reconstr Aesthet Surg 2012:65:e220-2.

Copyright 2018 BMJ Publishing Group. All rights reserved. For permission to reuse any of this content visit http://group.bmj.com/group/rights-licensing/permissions.

BMJ Case Report Fellows may re-use this article for personal use and teaching without any further permission.

Become a Fellow of BMJ Case Reports today and you can:

- Submit as many cases as you like

- Enjoy fast sympathetic peer review and rapid publication of accepted articles

- Access all the published articles

- Re-use any of the published material for personal use and teaching without further permission

For information on Institutional Fellowships contact consortiasales@bmjgroup.com

Visit casereports.bmj.com for more articles like this and to become a Fellow 